\title{
Morphology of Right Atrioventricular Valve -A Postmortem Study
}

\author{
Mahmuda Sultana ${ }^{* 1}$, Md. Tazul Islam ${ }^{2}$, Pran Krishna Basak ${ }^{3}$, Md. Samir Uddin ${ }^{4}$, Zakia Sultana ${ }^{5}$
}

\section{Abstract}

Introduction: Heart valves serve the important function of preventing backflow, or regurgitation, in the healthy heart. It is well known that cardiac valves can suffer from congenital and acquired disease. Most frequent acquired valvular abnormalities are stenoses of the aortic and mitral valves, which account for approximately 2/3rd of all valve disease. For the management of valvular disease morphology of right atrioventricular valve is essential. Materials and Methods: Study design was descriptive type of study. Place and period of study was Department of Anatomy, Sylhet MAG Osmani Medical College, Sylhet from July 2015 to June 2016. Results: Present study was performed on 70 post mortem human hearts of age ranging from 9 to 70 years. Human heart was collected from the unclaimed dead bodies autopsied in the department of Forensic medicine in Sylhet MAG Osmani Medical College during the study period fulfilling the inclusion criteria. Conclusion: The collected samples were divided into 3 groups depending on age. Group - A: (9 - 21 Years), Group - B: (22 - 41 Years), Group - C: ( 42 -70) Years. Each group was subdivided into two groups depending on their sex.

Key words: Atrioventricular valve, Heart.

Number of Tables: 02; Number of References: 12; Number of Correspondence: 06.

\section{*1. Corresponding Author: Dr. Mahmuda Sultana}

Assistant Professor

Department of Anatomy

Parkview Medical College, Sylhet.

Email : mahmudasultana90@gmail.com

Mobile : +8801793164303

2. Dr. Md. Tazul Islam

Lacturer, Department of Biochemistry

Sheikh Hasina Medical College, Hobigonj.

3. Dr. Pran Krishna Basak

Assistant Professor, Department of Anatomy Comilla Medical College, Comilla.

4. Dr. Md. Samir Uddin

Professor \& Head, Department of Anatomy Parkview Medical College, Sylhet.

\section{Dr. Zakia Sultana}

Professor \& Head, Department of Anatomy

Sylhet MAG Osmani Medical College, Sylhet.

\section{Introduction:}

The right atrioventricular or tricuspid valve guards the right AV orifice ${ }^{1}$. Through the right atrioventricular (tricuspid) orifice, the inflow part of the right ventricle receives blood from the right atrium, located posterior to the body of the sternum at the level of the 4th and 5th intercostal space ${ }^{2}$. The right atrioventricular orifice is somewhat oval or circular in outlet and is oriented almost vertically. It measures on average $11.4 \mathrm{~cm}$ in circumference in males and $10.8 \mathrm{~cm}$ in females ${ }^{1,3}$. The A-V valves (the tricuspid and mitral valves) prevent backflow of blood from the ventricles to the atria during systole. These valves close and open passively. That is, they close when a forward pressure gradient forces blood in the forward direction. For anatomical reasons, the thin, filmy $\mathrm{A}-\mathrm{V}$ valves require almost no backflow to cause closure ${ }^{4}$. The atrioventricular valve is developed by local proliferations of mesenchymal tissue after the fusion of atrioventricular endocardial cushions ${ }^{5,6}$. Replacement of damaged cardiac valves with prostheses has now become a common and often life-saving mode of therapy. This advancement has undoubtedly called for an improved anatomical knowledge on the part of the surgeon. Besides for correction of cardiac abnormalities modern cardiac surgery demands precise methods of investigation to provide accurate anatomical details. It is only when such information is available that a precise diagnosis can be planned ${ }^{7}$. This sort of information is undoubtedly best gathered through experience in the living subject, secondly to that approach and clearly prerequisite to the study of representative specimen such as anatomical study through autopsy.

\section{Materials and Methods:}

This descriptive study was conducted in the Department of Anatomy, in collaboration with the Department of Forensic Medicine, Sylhet MAG Osmani Medical College, Sylhet during the period from July 2015 to June 2016. Seventy human postmortem hearts were collected from the dead bodies autopsied within 36 hours of death. Considerable signs of decomposition or decomposed dead body, any gross heart disease were excluded. The obtained Hearts were classified according to the age and sex. Particulars of dead body was collected from police inquest report and chalan. Heart was collected after standard procedure of autopsy. Unwanted tissues were cleared and heart was washed thoroughly with normal saline and was gently squeezed to remove the clotted blood from the cavity of the heart. Congenital anomalies of heart was excluded after dissection. Each specimen was duly tagged by a piece of waxed cloth bearing an identifying number which was considered as serial number. Then the specimen was fixed and preserved in 10\% formalin.

\section{Grouping and distribution of cases}

The collected samples were divided into 3 groups depending on age.

Group - A: $\quad 9-21$ Years.

Group - B: $22-41$ Years.

Group-C: $42-70$ Years. 
Each group was subdivided into two groups depending on their sex. Parameter: Circumference of the right atrioventricular orifice.

Measurement of Parameter of the Right Atrioventricular Valve: Measurement of right atrioventricular orifices: For the measurement of the circumference of the right atrioventricular orifices the annulus of each orifice was cut open and stretched flat. A metric scale and non-stretchable nylon thread was used for this purpose. The latter used on base (annulus) of the cusps and subsequently stretched and compared with the metric scale. The values was expressed in centimeter.

Results:

Distribution of circumference of right atrio-ventricular orifice among different age group.

The circumference of right atrio-ventricular orifice was $6.62 \pm 1.80 \mathrm{~cm}$ in the age group-A (9-21 years), $9.02 \pm 1.27$ $\mathrm{cm}$ in the age group-B (22-41 years) and $8.73 \pm 1.33 \mathrm{~cm}$ in the age group- $\mathrm{C}$ (42-70 years). There was significant difference of circumference of right atrio-ventricular orifice between age group-A and age group- $B(p<0.001)$; and age group- $\mathrm{A}$ and age group- $\mathrm{C}(\mathrm{p}<0.001)$; but no significant difference between age group-B and age group-C $(p=0.504)$. Distribution of circumference of right atrio-ventricular orifice among different age group was shown in table I.

Table-I: Distribution of circumference of the Right atrio-ventricular orifice among different age group $(n=70)$.

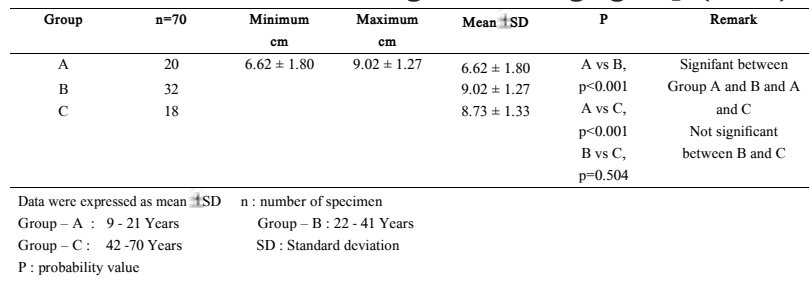

Distribution of circumference of right atrio-ventricular orifice between male and female:

The circumference of right atrio-ventricular orifice was $8.56 \pm 1.57 \mathrm{~cm}$ in male and $7.54 \pm 2.05 \mathrm{~cm}$ in female. There was significant difference of circumference of right atrio-ventricular orifice of heart between male and female $(t=2.266 ; p=0.027)$. Distribution of circumference of right atrio-ventricular orifice between male and female was shown in table II.

Table-II: Distribution of circumference of the right atrioventricular valve of heart between male and female $(n=70)$.

\begin{tabular}{|c|c|c|c|c|c|c|c|}
\hline Sex & $\mathrm{n}=70$ & $\underset{\mathrm{cm}}{\text { Minimum }}$ & $\underset{\mathrm{cm}}{\operatorname{Maximum}}$ & Mean $\pm S D$ & $\mathrm{t}$ & $\mathrm{p}$ & Remark \\
\hline Male & 49 & $4.47 \pm 2.53$ & $10.47 \pm 1.33$ & $8.56 \pm 1.57$ & 2.266 & 0.027 & Significantly \\
\hline Female & 21 & $2.03 \pm 1.03$ & $8.56 \pm 1.54$ & $7.54 \pm 2.05$ & & & greater in male \\
\hline D & sed & & nber of & imen & & & \\
\hline
\end{tabular}

\section{Discussion:}

This study showed that the circumference of right atrio-ventricular orifice was $6.62 \pm 1.80 \mathrm{~cm}$ in the age group-A (9-21 years), $9.02 \pm 1.27 \mathrm{~cm}$ in the age group-B (22-41 years) and $8.73 \pm 1.33 \mathrm{~cm}$ in the age group-C (42-70 years). There was significant difference of circumference of right atrio-ventricular orifice between age group- $\mathrm{A}$ and age group- $\mathrm{B}(\mathrm{p}<0.001)$; and age group- $\mathrm{A}$ and age group- $\mathrm{C}$ $(\mathrm{p}<0.001)$; but no significant difference between age group- $\mathrm{B}$ and age group- $\mathrm{C}(\mathrm{p}=0.504)$. The circumference of right atrio-ventricular orifice was $8.56 \pm 1.57 \mathrm{~cm}$ in male and $7.54 \pm 2.05 \mathrm{~cm}$ in female. There was significant difference of circumference of right atrio-ventricular orifice of heart between male and female $(\mathrm{p}=0.027)$.

Farzana $^{8}$ stated that the mean circumference of right atrioventricular orifice was $7 \pm 1.57,9.03 \pm 1.15$ and 9.51 $\pm 0.94 \mathrm{~cm}$ respectively. The mean difference of circumference of right atrioventricular orifice between Groups $\mathrm{A}$ and $\mathrm{B}, \mathrm{B}$ and $\mathrm{C}$ and $\mathrm{A}$ and $\mathrm{C}$ was statistically significant at $\mathrm{p}<.05$ level.

Begum $^{9}$ found that the mean circumference of the tricuspid orifice in male hearts was $9.24 \pm 1.19 \mathrm{~cm}$ and in females was $9.35 \pm 1.13 \mathrm{~cm}$. Statistical analysis however, showed no significant difference $(\mathrm{P}>0.05)$ in the circumference of tricuspid orifice between males and females.

Yavuz et $\mathrm{al}^{10}$ measured the mean circumference of the tricuspid orifice was $12.4 \pm 1.1 \mathrm{~cm}$ in males and $11.8 \pm 1.3$ $\mathrm{cm}$ in females.

Mannan ${ }^{11}$ measured the mean circumference of the tricuspid orifice and found $9.12 \mathrm{~cm}$ in males and $8.53 \mathrm{~cm}$ in females.

Datta $^{12}$ described that the right atrio-ventricular orifice is somewhat oval or circular in outline (depending upon the phase of the cardiac cycle) and the circumference of the opening, on an average, varies between $10 \mathrm{~cm}$ and $12 \mathrm{~cm}$.

Standring et $\mathrm{al}^{1}$ stated that circumference of the tricuspid orifice in males $11.4 \mathrm{~cm}$ and $10.8 \mathrm{~cm}$ in females.

The difference of the values of present study with the above cited literature is assumed to be due to racial cause.

\section{Conclusion:}

From the results a single set of conclusion could not drawn, but are expected to provide an idea about the circumference of the tricuspid orifice of the heart and their changes in relation to age and gender of Bangladeshi people.

\section{Conflict of Interest: None.}

\section{Acknowledgement:}

Thanks and all praise to Almighty Allah,the beneficial,the merciful for providing us enough energy and patience to complete the article. It is of my great pleasure to express my deepest regards to my respected teacher and guide Prof. Dr. Zakia Sultana, Professor and Head, Department of Anatomy, Sylhet MAG Osmani Medical College, Sylhet, for her scholastic guidance and valuable advice, constructive criticisms and constant inspiration from the beginning to the completion of this work within schedule time. I would like to thanks Prof. Dr. Md. Samir Uddin, Professor \& Head, Department of Anatomy, Parkview Medical College, Sylhet. I wish to thank all of my colleagues and the staff, Department of Anatomy Sylhet MAG Osmani Medical College, Sylhet, for their help in my efforts to complete this study. 


\section{References:}

1. Standring, S. Gray's Anatomy. 40th ed. Churchill Livingstone: Elsevier; 2008: 1245-5

2. Moore KL, Dalley AF, Agur AMR. Clinically Orientated Anatomy. 6th ed. Philadelphia: Lipincott Williams and Wilkins; 2010: 139.

3. McKinley M, O'Loughlin V. Human Anatomy. 3rd. New York: McGraw-Hill; 2012: 830-1.

4. Hall JE. Guyton and Hall Textbook of Medical Physiology. 12th eds. Philadelphia: Elsevier and Saunders; 2011: 103-9.

5. Sadler TW., editor. Langman's Medical Embryology. 12th ed. Philadelphia, Lippincott :Williams and Wilkins; 2012: 175 .

6. Moore KL, Persaud TVN. The Developing Human: Clinically Oriented Embryology. 8th ed. Elsevier Saunders; 2010: 350 .

7. Anderson JR, Zakkar M. Cardiac surgery. In: William N.S., Bulstrode, C.J.K. O'Connell, P.R., editors. Bailey and
Love's Short Practice of Surgery. 26th ed. Boca Raton: Taylor \& Francis; 2013: 823-49.

8. Farzana T. Anatomical Study on Post-Mortem Hearts with Its Vessels of Bangladeshi People (M Phil thesis). Dhaka: University of Dhaka; 2014.

9. Begum J. An Anatomical study of atrio-ventricular valves, muscular part of interventricular septum and papillary muscle of heart among the adult Bangladeshi people [Thesis]. Dhaka: University of Dhaka; 1996.

10. Yavuz KA, Govsa F, Ekin O, Boidak B, Ismail C. Structure of the human tricuspid valve leaflets and its chordae tendineae in unexpected death. Saudi Med J. 2004; 25(8): 1051-1058.

11. Mannan S. An anatomical study on post-mortem heart of Bangladeshi adult people (M Phil thesis). Dhaka: University of Dhaka; 2004.

12. Datta, A.K. Essentials of Human Anatomy. 9th ed. Kolkata: Current Books International. 2010; 1: 70. 